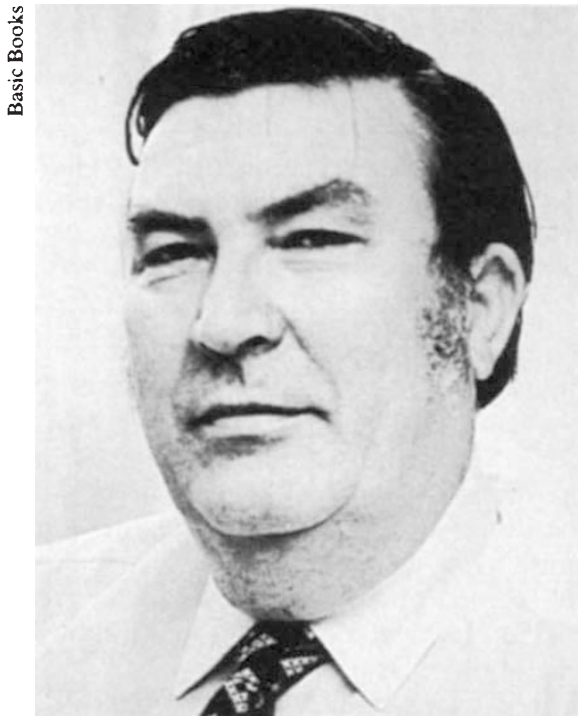

Herbert York - involvement in the future.

reaching out to meet the Soviets in this regard; by helping to build the University of California at San Diego; by returning to Washington in the Carter period, first to advise on defence matters and then as chief negotiator on the Comprehensive Test Ban; by entering again into public discussion of the nuclear future and founding his Institute on Global Conflict and Cooperation at San Diego, and rethinking how to influence the balance between maintaining the peace through the threat of mutual annihilation (which cannot be a permanent solution) and building a more secure alternative international relationship.

But the impact of the book is in its vignettes. For example, York brings to life the way the US approach to missiles developed in the mid-1950s through a number of small Defense Department Committees orchestrated by von Neumann. By the time von Neumann died (1955), the main elements of the US strategic missile programmes had been designed and development of them had begun. York is particularly persuasive in showing how these plans came to fruition despite the contrary public view due to the riveting success of Sputnik. The transfer of the 'outside expert committee' approach to broader issues, initiated by Eisenhower, faltered at first. York is unsparing in criticism of his own role in the Gaither Panel's (1957) alarmist assessment and in praising Eisenhower's good judgement in not implementing it. But with the appointment of James Killian to establish a new President's Science Advisory Committee (of which York was a member), the situation was redressed and planning for an innovative US space programme got under way in earnest.

In the summer of 1960 York suffered a serious heart attack. Not yet 40 , he retreated to the Chancellorship at San Diego where he subsequently became Graduate Dean and then Institute
Director. During most of the next 20 years he maintained an active role in a number of Washington assignments. His recognition of the potential role of arms control grew. He backed the mobile Midgetman, with its much lowered yield over the MX, throughout this period. And he was instrumental in delaying the development of anti-satellite systems, ending up as the Defense Department representative on negotiating a ban on them; the negotiations fell victim to the Soviet invasion of Afghanistan, but may have contributed to the very slow pace of development of such systems on both sides.

Early in 1979, before the anti-satellite negotiations collapsed, York was appointed chief US negotiator at the Comprehensive Test Ban talks. The timing was equally bad, but with perseverance much was accomplished during the year that remained before the election of Reagan and termination of the negotiations. York's detailed discussion of this period is among the most instructive parts of the book.

In the closing chapter York picks up his earlier involvement in the public consideration of arms control, recounting his

\section{Manual work}

\section{J. de Belleroche}

Neurochemistry: A Practical Approach. Edited by A.J. Turner and H.S. Bachelard. IRL Press: 1987. Pp.227. Hbk £26, $\$ 47$; $p b k £ 17, \$ 32$.

An invaluable book in the early days of neurochemistry was Practical Neurochemistry, by McIlwain and Rodnight, but since then there has been a reluctance on the part of researchers to write critically and instructively about methodological developments in the subject. This volume goes a long way towards filling the gap.

Nine approaches widely used in studies of the nervous system are discussed and assessed, and specific practical protocols are presented. The topics covered are subcellular fractionation, cell culture, immunocytochemistry, bioluminescence, receptors, protein phosphorylation, phosphoinositide turnover, isolation of cell nuclei and expression of receptor mRNA in Xenopus oocytes

The general format set by the editors is excellent - the procedures are laid out in clear steps and the information included is comprehensive in scope, with valuable notes about 'best buys'. This format still allows a measure of variety. Some chapters are arranged strictly as practical protocols (for example that on subcellular fractionation), while others (such as the chapter on neuroreceptors) are in a highly readable form and explain the pitfalls that meetings with the Pope and the Catholic bishops and giving his current reflections on the subject. He dwells effectively on his period of pessimism during the Vietnam War (in 1970 he wrote in Life magazine that "Unless we nerve ourselves to make the attempt [to roll back the arms race] and make it soon, we are quite simply doomed"). But by the end of this long account of his personal odyssey he has become more optimistic again:

notions that we must 'do something' radical about either the 'Soviet Threat' or the 'Nuclear Arms Race' very soon or be doomed have been with us for more than forty years. So far they have always proved to be wrong, and I expect they will remain so for the foreseeable future

If we are wise enough, we will use the [time which a balance of power is buying us] to find a way out of the grand nuclear dilemma.

This autobiography sets the standards of involvement that the post-nuclear generations will need if a way out is to be found.

Paul Doty is Mallinckrodt Professor of Biochemistry at Harvard University, and Director Emeritus of the Center for Science and International Affairs, John F. Kennedy School of Government, Cambridge, Massachusetts 02138, USA.

have been encountered in the development of particular techniques.

Other contributions, such as those on bioluminescence and protein phosphorylation, provide the meticulous detail needed to translate the information into practice and thereby save many hours of trial and error in finding the optimal conditions or best source of materials. Another attractive feature of these chapters is the illustration of the methods they describe with typical experimental results. The accounts of cell culture and immunocytochemistry also provide a comprehensive background for beginners embarking on work using these approaches.

Techniques such as Xenopus oocyte translation of exogenous mRNA have made a fundamental contribution to our understanding of the nature of oligomeric receptor proteins, notably the nicotinic receptor. The account of the properties of Xenopus that make this possible, along with further applications of the method, make an interesting contribution.

There is certainly a need for a book of this kind, both as a laboratory manual and to provide critical appraisals of methods currently being used and developed. Although a broad selection of techniques is covered in the book, a number of other aspects of neurochemical methods would benefit from the same treatment, and I look forward to a future volume added to the Practical Approach series.

$J$. de Belleroche is in the Department of Biochemistry, Charing Cross and Westminster Medical School, Fulham Palace Road, London W6 $8 R F, U K$ 